\title{
DÜBLIN
}

Technological University Dublin

ARROW@TU Dublin

Conference Papers

School of Transport Engineering, Environment and Planning

2008-06-23

\section{Metrology and Proportion in the Ecclesiastical Architecture of Medieval Ireland}

\author{
Avril Behan \\ Technological University Dublin, avril.behan@tudublin.ie \\ Rachel Moss \\ University of Dublin, Trinity College, rmoss@tcd.ie
}

Follow this and additional works at: https://arrow.tudublin.ie/beschspcon

Part of the Ancient, Medieval, Renaissance and Baroque Art and Architecture Commons, Architectural History and Criticism Commons, Geometry and Topology Commons, and the Other Engineering Commons

\section{Recommended Citation}

Behan, A., Moss, R.: Metrology and proportion in the ecclesiastical architecture of medieval Ireland. Nexus VII: Architecture and Mathematics, Kim Williams Books, Turin, Italy, vol. VII, pp. 171-83.

This Conference Paper is brought to you for free and open access by the School of Transport Engineering, Environment and Planning at ARROW@TU Dublin. It has been accepted for inclusion in Conference Papers by an authorized administrator of ARROW@TU Dublin. For more information, please contact arrow.admin@tudublin.ie, aisling.coyne@tudublin.ie,gerard.connolly@tudublin.ie.

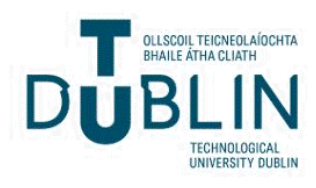




\title{
METROLOGY AND PROPORTION IN THE ECCLESIASTICAL ARCHITECTURE OF MEDIEVAL IRELAND
}

\begin{abstract}
Avril Behan ${ }^{1}$ and Rachel Moss ${ }^{2}$
Abstract. The aim of this paper is to examine the extent to which detailed empirical analysis of the metrology and proportional systems used in the design of Irish ecclesiastical architecture can be analysed to provide historical information not otherwise available. Focussing on a relatively limited sample of window tracery designs as a case study, it will first set out to establish what, if any, systems were in use, and then what light these might shed on the background, training and work practices of the masons, and, by association, the patrons responsible for employing them.
\end{abstract}

\section{Introduction}

The 1140s marked a turning point in Irish monastic architecture. Up to the twelfth century Irish monasteries had typically comprised an apparently random collection of small buildings, the churches small in scale and simple in planning. The introduction of European monastic orders, in particular the Cistercians, was to lead to a revolution in both the layout and the aesthetic of monastic architecture, a topic which has received much attention from architectural historians over the years. However, the technologies required to achieve this revolution - in particular, the proportional systems and metrology used - have come under less scrutiny. While a small number of scholars have acknowledged a consciousness of the use of proportional systems, few have explored in any depth how the adoption of particular systems may have affected the overall design of buildings, in particular their detailing; what they tell us about the origins and training of the craftsmen who were using them; and what a study of the development of such systems can add to the poorly documented building history of Ireland.

\section{Parameters of the study}

Metrology and systems of proportion have only been touched on in literature dealing with Irish architectural history. A number of commentaries on a tenth- to twelfth-century Irish law tract, which deals with the costing of ecclesiastical buildings, including round towers, conclude that the standard proportionate system

\footnotetext{
1 Department of Spatial Information Sciences, School of Spatial Planning, Dublin Institute of Technology, Bolton Street, Dublin 1, IRELAND, avril.behan@dit.ie

2 Department of the History of Art and Architecture, School of Histories and Humanities, University of Dublin, Trinity College, Dublin 2, IRELAND, rmoss@tcd.ie
} 
for early single cell churches was $1.5: 1 .^{3}$ The foot or traig was the unit of measurement used, but as yet the exact value of this is unclear. Stalley examined the proportions and systems of measurement of round towers, concluding that many towers appear to have adhered to a 1:2 ratio of circumference to height, and, certainly in the case of Glendalough tower, the English foot $(0.3048 \mathrm{~m})$, which may have been equivalent to a traig, was the unit of measurement used [Stalley 2001]. Almost without exception the study of proportionate systems in later medieval Irish architecture has been limited to an examination of the use of $\sqrt{2}$ and the golden section in the laying out of monasteries and parish churches from the twelfth to the fifteenth centuries. ${ }^{4}$ While there is a general consensus that both methods were engaged, there has been little attempt to expand this line of enquiry into the use of similar systems in the design of elevations and architectural detailing, or to look at the units of measurement used. As has been demonstrated by a number of studies from continental Europe [Paul 2002; Davis 2002; James 1973], this methodology can prove particularly successful in the study of window tracery. Tracery, having both structural and artistic functions, is an indicator of the abilities of the mason in two important elements of the craft; design and stereotomy [Curl 1992]. In addition, in an Irish context, the sponsorship of windows is one of the most frequently documented activities relating to building history, allowing firm conclusions to be drawn regarding the context in which such designs were created. ${ }^{5}$

This study will focus on the tracery of a group of buildings with similar 'looped' tracery. Fig. 1 shows the locations of the selected sites overlaid on the medieval kingdom boundaries c. 1534 suggested by K.W. Nicholls [1976].

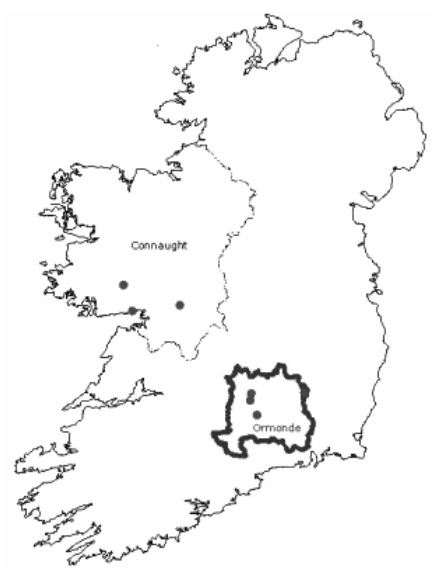

Fig. 1. Site Locations shown against medieval kingdom boundaries c. 1534 (after [Nichols 1976])

\footnotetext{
3 The original manuscript text of the law is in Trinity College Dublin MS H.3.17. The most comprehensive discussion of the text is in [Long 1996: 141-164].

${ }^{4}$ For Cistercian and Franciscan planning see [Stalley 1987; Stalley 1990]. For proportional systems in medieval parish churches see [O'Neill 2002]. For medieval friaries in Connaught see [Mannion 1997].

${ }^{5}$ For example references to several schemes of refenestration are mentioned in the medieval Register of Athenry Friary; see [Coleman 1912]. For other references, see [Moss 2006].
} 
The occurrence of this particular form of tracery is relatively widespread, both regionally and temporally. For the purposes of this study two clusters located in regions under different political control during the later middle ages, one Gaelic and one Anglo-Norman, have been selected (see fig. 2 and Table 1). Although difficult to date with any precision, buildings that range in date from the late thirteenth to the sixteenth centuries have been included in the study in order to establish whether any degree of continuity etc. can be detected. The buildings chosen also vary in the type of establishment, with the sample covering each of the main orders (Augustinian, Cistercian, Dominican \& Franciscan) as well as a collegiate church and a cathedral.

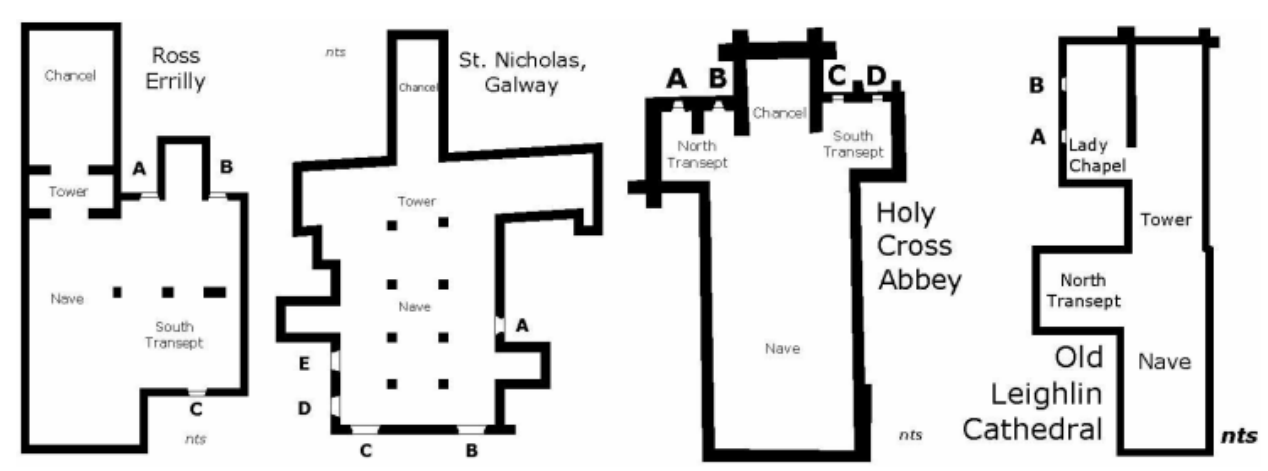

Fig. 2.Ground plans of Ross Errilly, St. Nicholas', Galway, Holy Cross and Old Leighlin showing window locations (not to scale)

\begin{tabular}{|c|c|c|c|c|}
\hline Site Name & $\begin{array}{l}\text { Medieval } \\
\text { Kingdom } \\
\end{array}$ & $\begin{array}{l}\text { Window } \\
\text { Location } \\
\end{array}$ & $\begin{array}{c}\text { Window } \\
\text { Orientation }\end{array}$ & $\begin{array}{l}\text { Modern } \\
\text { County } \\
\end{array}$ \\
\hline $\begin{array}{l}\text { Meelick Franciscan } \\
\text { Friary }\end{array}$ & Connaught & Chancel & East & Galway \\
\hline \multirow{2}{*}{$\begin{array}{l}\text { Ross Erilly } \\
\text { Franciscan Friary }\end{array}$} & Connaught & South Transept & East (A \& B) & Galway \\
\hline & & South Transept & West (C) & \\
\hline \multirow{3}{*}{$\begin{array}{l}\text { St. Nicholas' } \\
\text { Collegiate Church, } \\
\text { Galway }\end{array}$} & Connaught & Nave & South (A) & Galway \\
\hline & & Nave & North (D \& E) & \\
\hline & & Nave & West (B \& C) & \\
\hline $\begin{array}{l}\text { Fethard Augustinian } \\
\text { Abbey }\end{array}$ & Ormond & South Transept & East & Tipperary \\
\hline \multirow{2}{*}{$\begin{array}{l}\text { Holycross Cistercian } \\
\text { Abbey }\end{array}$} & Ormond & North Transept & East (A \& B) & Tipperary \\
\hline & & South Transept & East (C \& D) & \\
\hline $\begin{array}{l}\text { St. Laserian's } \\
\text { Cathedral, Old } \\
\text { Leighlin }\end{array}$ & Ormond & North Chapel & North (A \& B) & Carlow \\
\hline $\begin{array}{l}\text { St. Dominic's } \\
\text { Dominican Friary, } \\
\text { Cashel }\end{array}$ & Ormond & South Transept & South & Tipperary \\
\hline
\end{tabular}

Table 1. Sample of medieval sites containing looped tracery 


\section{Field data collection}

Since this study is empirical rather than stylistic, the primary requirement is the collection of detailed measurements of looped tracery at the selected sites. For this particular evaluation measurements in all three dimensions (plan and elevation) are required, an exercise best achieved through the generation of 3D models of the tracery (fig. 3). Although a number of methods exist for the production of such models, ${ }^{6}$ stereo photogrammetry ${ }^{7}$ was chosen. This method results in the creation of true-to-scale 3D models, created using a small number of reference (control) measurements and a pair of photographs, which also have a wide range of interpretative uses. ${ }^{8}$ This technique also has the advantage of using relatively inexpensive field equipment: ${ }^{9}$ for this study photographs were taken using a Nikon D70 with $18-70 \mathrm{~mm}$ Nikkor lens, while a Leica TPS 1205 reflectorless total station ${ }^{10}$ was used to collect the control (scale and orientation) information.

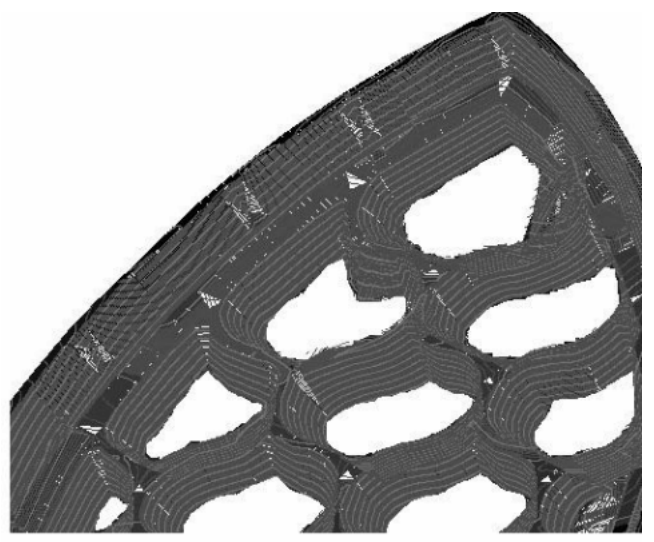

Fig. 3. 3D model of tracery with overlaid contours

\footnotetext{
${ }^{6}$ Other options include terrestrial laser scanning and discrete point/line measurement using a reflectorless total station. The total station option was rejected because the required field time was prohibitive for the number of sites being visited for the ongoing project. Terrestrial laser scanning was not used due to the unavailability of equipment, because there would be no gain in accuracy, and because significantly more field time would be required without a commensurate reduction in processing time.

Photogrammetry is the science of generating measurements from imagery. Stereo photogrammetry uses two photographs captured and viewed in a simulation of the way human eyes achieve depth perception from offset images.

8 This is to be compared with the results of terrestrial laser scanning, which although usually accompanied by supporting photographs, requires a detailed understanding of the handling of point clouds (set of 3D points) to ensure the best results.

9 Suitable digital cameras cost between $€ 500$ and $€ 1000$; reflectorless total stations of sufficient accuracy cost about $€ 12,000$. This is still inexpensive when compared to a terrestrial laser scanner price of more than $€ 80,000$

${ }^{10}$ The reflectorless total station generates a 3D coordinate for any point, identified by the operator with the crosshairs of a telescope, using horizontal and vertical angle measurements and a distance measured using a time-of-flight laser. The calculation is based on trigonometric formulae and is a standard surveying technique.
} 
The field activities required for each window of interest were as follows:

- A pair of photographs of the window was acquired. The required conditions for the photo pair were as follows:

$\circ$ the plane of the camera sensor (the camera back) was aligned approximately parallel to the main plane of the window;

0 the two photographs were taken such that they overlapped by between $70 \%$ and $80 \%$;

- auto-focus was switched off and focus was set to infinity, and

- a light-meter was used to ensure sufficient radiometric quality of the images.

- The relative positions of a minimum of three control points were measured in three dimensions - here the reflectorless total station was used. The points were clearly identifiable in the photographs and could be measured unambiguously using the total station. In this study, typically between 6 and 12 control points were measured to ensure redundancy. ${ }^{11}$

\section{Processing}

To generate the 3D model from the stereo imagery the processing package Leica Photogrammetric System (LPS) was used in combination with Autodesk Civil 3D $2007 / 2008$. $^{12}$ The processing steps involved were as follows:

- The control was checked using Civil 3D to ensure that the $x-y$ plane of the coordinate system was parallel to the plane of the camera sensor (this was a requirement of the LPS software);

- Orientation was established by measuring the exact relative geometries of the images at the time of capture and defining the positions of the control points on both photographs to assign a scale to the stereo model in three dimensions;

- A 3D digital model of the tracery was generated using LPS's Automatic Terrain Extraction method, which uses image matching techniques ${ }^{13}$ to define 3D coordinates for a grid of points laid across the model;

\footnotetext{
11 This level of redundancy was required mainly because the chosen control points were naturally occurring (e.g., sharp corners on stonework or patterns caused by lichens) or pre-existing features (e.g., screws holding protective grilles or metal bars used to prevent unauthorised entry to sites). To generate the highest accuracy photogrammetric products it is advisable to use man-made targets (typically plastic cards or reflective stickers) but these could not be used in this survey because of the delicate nature of some of the sites (and the potential damage that the targets might cause) and the inaccessibility of the features (lifting or hoisting equipment could not have been used in many of the locations because of issues of topography and the position of the features in very close proximity to modern graves). The extra points enabled detailed accuracy checking after the modelling procedure.

${ }^{12}$ This is a Computer Aided Drafting package with a number of enhancements for the better handling of survey generated data and the manipulation and visualisation of three-dimensional models.

${ }^{13}$ Image matching involves automatically checking the levels of similarity between pixels in the overlapping images to find the best correspondence. Once identikit pixels have been found, a space intersection can be carried out using the orientation information previously calculated from the control information to generate a 3D coordinate for the matched point.
} 
- The quality of the 3D model was improved by removing erroneous points and adding breaklines. In LPS an operator, viewing in stereo, can define points or lines in 3D, ensuring that major features (such as significant changes of direction in the moulding profiles) are accurately included. ${ }^{14}$

\section{Information extraction}

For each window a number of key elements was extracted from the 3D model. Table 2 lists the nine key dimensions extracted for each window, while Table 3 lists the nine derived proportions (since the intention of the mason with regards to important dimensions and proportions is not known, a number of variations have been examined, e.g., height to springing of the arch or to its peak). A list of all extracted dimensions and proportions is available from the authors.

\begin{tabular}{||l||l|l|l||}
\hline \multicolumn{1}{|l||}{ Item of Interest } & \multicolumn{3}{c||}{ Quantity } \\
\hline \hline Full window & (i) Width & (ii) Overall height & (iii) Height to springing of the arch \\
\hline Light & (iv) Width & (v) Overall height & (vi) Height to springing of the arch \\
\hline Arch & (vii) Span & (viii) Height & \\
\hline Mullion & (ix) Width & & \\
\hline
\end{tabular}

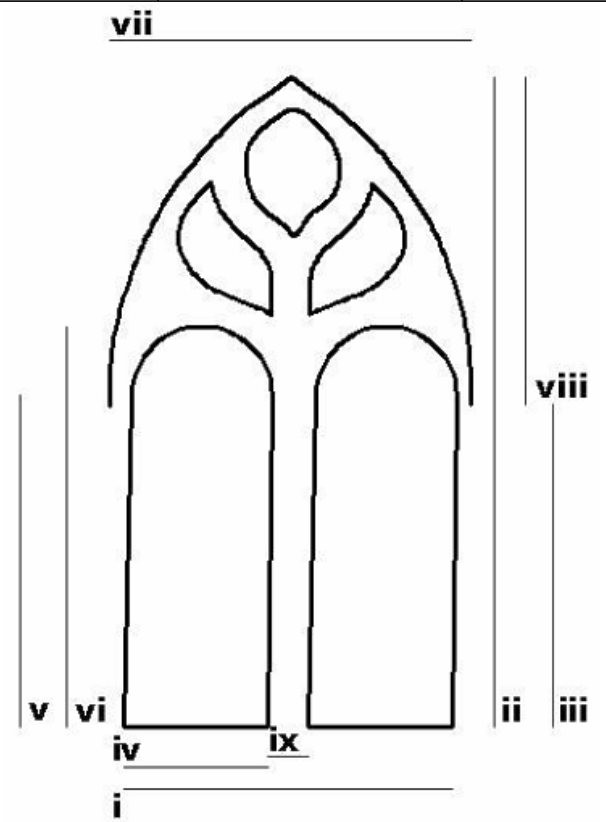

Table 2 (above). Details of extracted dimensions

Fig. 4 (below). Diagram showing the locations of extracted dimensions

\footnotetext{
${ }^{14}$ While image-matching techniques are relatively robust the LPS software was primarily designed for aerial photogrammetric work and, thus, needs operator input to ensure the highest quality of resultant 3D model.

${ }^{15}$ For the measurement of light widths, where possible, an average was taken between the width at the base of the light and at the spring of the arch.
} 


\begin{tabular}{||l||l|l|l||}
\hline \multicolumn{1}{||c||}{$\begin{array}{c}\text { Item of } \\
\text { Interest }\end{array}$} & \multicolumn{3}{|c||}{ Proportion } \\
\hline \hline Full window & $\begin{array}{l}\text { Tracery field height to } \\
\text { light height (at springing } \\
\text { point) }\end{array}$ & $\begin{array}{l}\text { Tracery field height to } \\
\text { light height (at arch peak) }\end{array}$ & $\begin{array}{l}\text { Overall width to overall } \\
\text { height }\end{array}$ \\
\hline Light & $\begin{array}{l}\text { Light width to light height } \\
\text { at springing point) }\end{array}$ & $\begin{array}{l}\text { Light width to light height } \\
\text { (at arch peak) }\end{array}$ & $\begin{array}{l}\text { Window width to light } \\
\text { height }\end{array}$ \\
\hline Mullion & $\begin{array}{l}\text { Mullion width to overall } \\
\text { window width }\end{array}$ & $\begin{array}{l}\text { Normalised mullion width } \\
\text { to overall window width } \\
\text { (based on number of } \\
\text { mullions) }\end{array}$ & \\
\hline
\end{tabular}

Table 3. Details of proportions studied

\section{Analysis}

Seven different sites with a collective total of seventeen looped-tracery windows were surveyed. Nine sets of proportions and nine measurements were recorded for each window.

\section{Proportional analysis}

Following the model of previous studies, proportional analysis was carried out initially through a search for proportions known to have been used in Irish medieval architecture, such as the Golden Section or $1: \sqrt{2}$ relationships. In Britain and continental Europe authors have found evidence for the use of both of these relationships as well as $1: \sqrt{ } 3$ and less geometrically-based proportions such as 1:2, $1: 3$ and 1:4. Reuse of the same measurement, i.e., a 1:1 relationship, has also been examined. Each potential proportional relationship within the sample of 17 windows was examined in normal and inverted forms producing a total of 306 proportions.

A search for each possible relationship was made within the 306 proportions extracted. Since the measurements can vary from their true value due to variables such as the photograph orientation process, human error in the measurement phase, and weathering of the stone, a range of values distributed about each ideal proportion were examined. $\pm 5 \%$ was added to each ideal proportion to generate a range of values that mirrors statistical norms of $95 \%$ confidence intervals.

\section{Golden Section, $1: \sqrt{ } 2$ and $1: \sqrt{ } 3$}

Limited evidence for the occurrence of the Golden Section, $1: \sqrt{2}$ and $1: \sqrt{3}$ proportionate systems was detected in the analysis of tracery from the study sample. The nature and distribution of the elements where such systems were detected suggest a random rather than deliberate use in the design process.
$1: 2$
0.5
(range 0.525 - 0.475)
$1: 3$
0.333 (range $0.350-0.316$ )
1:1
(range 1.050 - 0.950) 

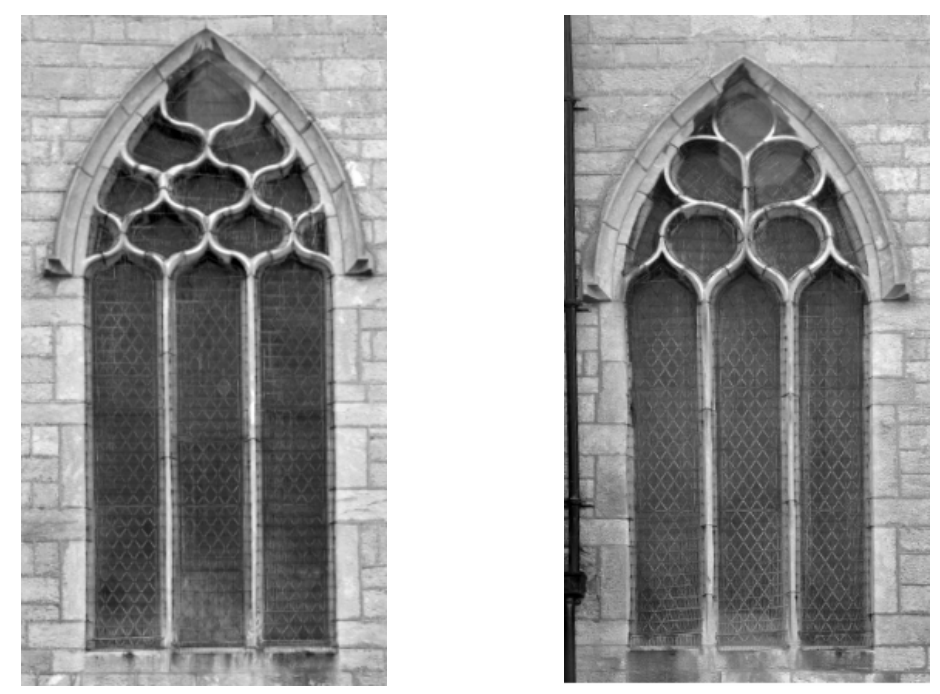

Fig. 5. St. Nicholas' Collegiate Church, North Windows E (left) and D (right)

The relationship of 1:2 occurs eight times overall; in three cases in the category "Overall window width to overall window height" and in the other three as "Window width to light height (at arch peak)". In each of these six cases another proportion or regular relationship is also evident in the data. For the two north nave windows of St. Nicholas' (fig. 5) the 1:2 relationship of window width to light height is accompanied by a 1:3 relationship between the window's width and its height. The other proportions for these two windows also display similarities when compared. Interestingly the tracery in these two windows is quite different in character, although both fall within the category of the looped style.

At Fethard Augustinian the 1:3 relationship is also demonstrated for light width to height in combination with the 1:2 ratio for overall window width to height in the east window of the south transept. At Old Leighlin Cathedral the 1:2 ratio occurs twice (window width to light height and tracery height to light height) in the eastern north-facing window of the Lady Chapel (B in fig. 2) with the 1:3 ratio evident in the proportion of overall window width to height. At St. Dominic's, Cashel, the 1:2 relationship of window width to height is accompanied by a 1:1 ratio between window width and light height in the nave south window. The fact that both proportions are width to height could point to a deliberate plan by the mason.

Perhaps of most interest is the occurrence of four identifiable proportions in the northeastern window of the north transept at Holycross (A in fig. 2). In this one window there are two occurrences of 1:1 ratios and one each of 1:2 and 1:3. The result, not unsurprisingly, is an aesthetically pleasing window of beautiful proportions (fig. 6). At the same site, the two east windows in the south transept also utilise the 1:1 proportion and are very close to using the 1:2. As at St. Nicholas' the tracery designs of the two windows are quite different but these similarities in measurements and proportions hint that the work had the same basis. 


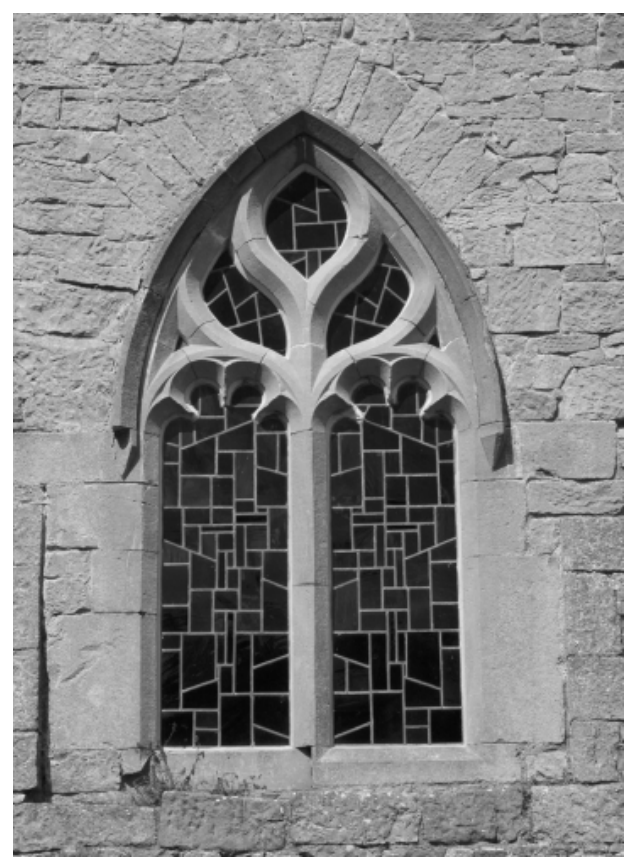

Fig. 6. Beautifully proportioned north transept (north eastern) window at Holycross

Holycross underwent a major programme of renovations during the fifteenth century which, although not documented, can be closely linked to members of the powerful Butler family through the incorporation of heraldry in the fabric of the church. A recent study of moulding profiles in the abbey church has led Danielle O'Donovan [2007] to suggest that Holycross provided a major hub for masons brought into the area by the Butlers, whose work was subsequently emulated throughout the territory. The relatively rare occurrence of such a perfect set of proportions in the window help to reinforce this argument, suggesting perhaps the work of a craftsman trained in the basic principals of design.

\section{$1: 4$}

0.250 (range $0.263-0.238$ )

The final standard ratio worth mentioning occurs in four windows at three sites and in all cases represents the relationship between light width and light height. All four windows have two lights, but the examples at Ross Errilly and Old Leighlin are very simple in tracery style, while that at Holy Cross is more complex.

\section{Metrological investigation}

Eric Fernie, James Addiss and others have highlighted the many potential pitfalls that exist in establishing the units of measurement used in a medieval building, suggesting that "one can get any foot from any building" (Raper 1760, cited in [Fernie 2002]). This study has been careful to follow Addiss's recommendation of using "explicit and comprehensive" measurement as a means of increasing the probability that the conclusions drawn will be correct [Addiss 2002]. 
In order to conduct an objective metrological investigation, an adaptation of $\mathrm{F}$. Bettess's methodology was used [Bettess 1991]. This method is based on the principle of 'least squares' and offers significant flexibility by supporting full units and their fractions. Each measurement taken from the sample window is divided, in turn, by a range of potential units resulting in an integer value plus a remainder $(A=I$ $+r$ ). Since it is known that medieval masons used full units and halves, thirds and quarters thereof, the remainder is evaluated for similarity to each of these for each candidate unit (i.e., $r$ is compared with $\mathrm{I} / 2, \mathrm{I} / 3, \mathrm{I} / 4,2 \mathrm{I} / 3$ and $3 \mathrm{I} / 4$ ). Based on an analysis of known medieval foot units, a range of sample units from $0.249 \mathrm{~m}$ to $0.325 \mathrm{~m}$, were selected for the study [Zupko 1978; Stalley 2001; Bettess 1991; Addiss 2002].

\begin{tabular}{|c|c|c|c|c|}
\hline $\begin{array}{l}\text { Probable } \\
\text { Unit }\end{array}$ & Location & $\begin{array}{c}\text { Closest Known } \\
\text { Unit }\end{array}$ & Difference & $\begin{array}{c}\text { Sample Size } \\
\text { (number of } \\
\text { windows and } \\
\text { measurements) }\end{array}$ \\
\hline 0.309 & $\begin{array}{l}\text { St. Dominic's, } \\
\text { Dominican Friary, } \\
\text { Cashel, Tipperary }\end{array}$ & $\begin{array}{c}0.3048 \\
\text { Standard } \\
\text { English Foot }\end{array}$ & 0.0042 & $1 \& 9$ \\
\hline 0.319 & $\begin{array}{l}\text { Fethard Augustinian } \\
\text { Abbey, Tipperary }\end{array}$ & $\begin{array}{c}0.3167 \\
\text { English } \\
\text { Medieval Foot }\end{array}$ & 0.0023 & $1 \& 9$ \\
\hline 0.320 & $\begin{array}{l}\text { St. Laserian's } \\
\text { Cathedral, Old Leighlin }\end{array}$ & $\begin{array}{c}0.3167 \\
\text { English } \\
\text { Medieval Foot }\end{array}$ & 0.0033 & $2 \& 18$ \\
\hline 0.285 & $\begin{array}{l}\text { Holy Cross Cistercian } \\
\text { Abbey, Tipperary }\end{array}$ & $\begin{array}{c}0.2800 \\
\text { Anglo-Saxon } \\
\text { Foot }\end{array}$ & 0.0050 & $4 \& 36$ \\
\hline 0.284 & Kingdom of Ormond & $\begin{array}{c}0.2800 \\
\text { Anglo-Saxon } \\
\text { Foot }\end{array}$ & 0.0040 & $8 \& 72$ \\
\hline 0.295 & $\begin{array}{l}\text { Meelick Franciscan } \\
\text { Friary, Galway }\end{array}$ & $\begin{array}{c}0.3048 \\
\text { Standard } \\
\text { English Foot } \\
\end{array}$ & 0.0098 & $1 \& 9$ \\
\hline 0.299 & $\begin{array}{l}\text { Ross Errilly Franciscan } \\
\text { Friary, Galway }\end{array}$ & $\begin{array}{c}0.3048 \\
\text { Standard } \\
\text { English Foot }\end{array}$ & 0.0058 & $3 \& 27$ \\
\hline 0.317 & $\begin{array}{l}\text { St. Nicholas' } \\
\text { Collegiate Church, } \\
\text { Galway }\end{array}$ & $\begin{array}{c}0.317 \\
\text { English } \\
\text { Medieval Foot }\end{array}$ & 0.0000 & $5 \& 45$ \\
\hline 0.269 & $\begin{array}{l}\text { Kingdom of } \\
\text { Connaught }\end{array}$ & $\begin{array}{c}0.2800 \\
\text { Anglo-Saxon } \\
\text { Foot } \\
\end{array}$ & 0.0110 & $9 \& 81$ \\
\hline 0.275 & Full Sample & $\begin{array}{c}0.2800 \\
\text { Anglo-Saxon } \\
\text { Foot }\end{array}$ & 0.0050 & $17 \& 153$ \\
\hline
\end{tabular}

Table 4. Most probable units from analysis related to known units (all unit and difference values are quoted in metres) 
The analysis steps were as follows:

1. Each window measurement (Table 2) was divided by the sample unit;

2. The difference was calculated between the remainder and the unit, and between the remainder and each of the standard fractions of the unit (half, quarter, third, two-thirds, three-quarters);

3. The minimum difference calculated in step 2 is extracted - this is taken to denote the most probable unit plus fraction combination (the fraction can, of course, equal zero indicating that an integer number of units was used);

4. The variances of the minimum differences chosen in step 3 were calculated for:

- Each site

- Each region

- The full data set;

5. The variances in each category were compared and the minimum value extracted, resulting in Table 4 which lists the most probably metric unit value for each site, each region and for the full dataset;

6. The probable units were compared with proven units of measurement.

While it is possible that measurements made by medieval masons may have been based on a small unit such as a palm or a span, this investigation focussed on a limited selection of 'foot' values that are known to have been used in the period. The options chosen are: the standard English Foot $(0.3048 \mathrm{~m})$, which was shown by Roger Stalley to have been in use in early medieval times; the English Medieval Foot $(0.3167 \mathrm{~m})$, used for building works in England and believed to be derived from the Greek Common Foot; and the Anglo-Saxon Foot $(0.2800 \mathrm{~m})$, reported by Bettess in his studies at Jarrow and Yeaverling [1991]. ${ }^{16}$

\section{Units of measurement}

As with the proportional systems examined above, the random nature of measurements close to the Standard English and Anglo-Saxon foot values suggests that they were not used in the building sample chosen here.

The most compelling evidence is for use of the English medieval foot of $0.317 \mathrm{~m}$. It appears as the most viable candidate at three sites, Old Leighlin and Fethard Augustinian church in Ormond, and St Nicholas' Collegiate Church in Gaelic Connaught, where the match is very good. ${ }^{17}$

Little is known of the history of the two Ormond sites; the construction of the Lady chapel in which the Old Leighlin windows are found is usually associated with

\footnotetext{
${ }^{16}$ For a list of comparative linear measures, see [Zupko 1977] and [Strayer 1989: 580-596]. For a similar list including the English Medieval Foot (based on the Greek Common Foot and used for buildings) see [Skinner 1967].

${ }_{17}<3 \mathrm{~mm},<2 \mathrm{~mm}$ and $<1 \mathrm{~mm}$ respectively - it is acknowledged that this level of accuracy is not possible from the original measurement method but the results are analysed here relative to the other measurements in the group, rather than in their absolute form.
} 
the episcopate of Matthew Sanders, the Drogheda-born bishop between 1527-1549, who is also credited with the 'erection and glazing' of the south window in the church [Ware 1739-1746: I, 461]. Of the construction of the south transept at Fethard, nothing is known. In Galway, however, we are on safer ground. A manuscript preserved in Trinity College entitled "Account of the town of Galway" records that in the year 1538 during his mayoralty of Galway, "John French alias Shane Itallen, soe called on account of the abundance of salt that he brought into the country, built the north side of the church" (p. 10). Isolated among other Connaught examples, it is tempting to see the effect of this influential and well-travelled patron at work in the design of the windows, possibly introducing professionally-trained masons into the area to conduct this work

\section{Conclusion}

The sample of just seventeen windows examined from only seven sites is, of course, small, and results gleaned from this survey cannot be seen as conclusive. However, preliminary findings suggest that the areas of medieval metrology and proportionate systems in design do have the potential to provide empirical evidence for the work of professionally-trained masons in Ireland, and to distinguish them from craftsmen who had the ability to copy architectural form, but without understanding the underlying principals of design.

\section{References}

AdDISS, James. 2002. Measure \& Proportion in Romanesque Architecture. Pp. 57-82 in Ad Quadratum: the Practical Application of Geometry in Medieval Architecture, Nancy Wu, ed. Aldershot, England: Ashgate.

BetTess, F. 1991. The Anglo-Saxon Foot: A Computerised Assessment. Medieval Archaeology 35: 44-50.

Coleman, Ambrose, ed. 1912. Regestum monasterii fratum praedicatorum de Athenry. Archivium Hibernicum 1: 201-221.

CuRL, James Stevens. 1992. The art of cutting and dressing of stones. P. 297 in Encyclopaedia of Architectural Terms. Dorset, England: Donhead.

DAVIS, Michael T. On the Drawing Board: Plans of the Clermont Cathedral Terrace, Pp. 183204 in Ad Quadratum: the Practical Application of Geometry in Medieval Architecture, Nancy Wu, ed. Aldershot, England: Ashgate.

FERNIE, Eric. 2002. Introduction. Pp. 1-9 in Ad Quadratum: the Practical Application of Geometry in Medieval Architecture, Nancy Wu, ed. Aldershot, England: Ashgate.

JAMES, John. 1973. Medieval geometry: the Western Rose of Chartres Cathedral. Architectural Association Quarterly (AAQ) 5, 2: 4-10.

LonG, W.H. 1996. Glendalough, Co. Wicklow: An Interdisciplinary Study. Ph.D. thesis, Trinity College Dublin.

MANNION Susan. 1997. A study of the physical remains of the medieval friaries of Connacht. Ph.D. thesis, Queen's University, Belfast.

Moss, Rachel. 2006. Permanent expressions of piety: the secular and the sacred in later medieval stone sculpture. Pp. 72-97 in Art and Devotion in Late Medieval Ireland, Rachel Moss, Colmán O Clabaigh and Salvador Ryan, eds. Dublin: Four Courts Press.

NichOLLS, K.W. 1976. Lordships of Ireland c.1534. Oxford: Oxford University Press. 
O'Donovan, Danielle. 2007. Building the Butler Lordship 1405 -c. 1552. Ph.D. thesis, Trinity College Dublin.

O'NeILl, Michael. 2002. The Medieval Parish Churches in County Meath. Journal of the Royal Society of Antiquaries of Ireland 132: 1-56.

Paul, Vivian. 2002. Geometry Studies: The Blind Tracery in the Western Chapels of Narbonne Cathedral. Pp. 205-216 in Ad Quadratum: the Practical Application of Geometry in Medieval Architecture, Nancy Wu, ed. Aldershot, England: Ashgate.

SkINNER, F. G. 1967. Weights and Measures: their Ancient Origins. London: Her Majesty's Stationery Office.

StALlEY, Roger. 1987. The Cistercian Monasteries of Ireland. London and New Haven: Yale University Press.

- 1990. Gaelic Friars and Gothic Design. Pp. 191-202 in Medieval Architecture and its Intellectual Context, Paul Crossley and Eric Fernie, eds. London: Hambledon Continuum. . 2001. Sex, Symbol and Myth: Some Observations on Irish Round Towers. Pp. 2748 in From Ireland Coming: Irish Art from the Early Christian to the Late Gothic Period and its European Context, Colum Hourihane, ed. Princeton: Princeton University Press.

Strayer, J.R., ed. 1989. Dictionary of the Middle Ages. 13 Vols. New York: Charles Scribner's Sons.

WARE, James, Sir. 1739-1746. The works of Sir James Ware concerning Ireland revised and improved. 3 vols. Dublin.

ZuPKO, Ronald Edward. 1978. British Weights and Measures: A History from Antiquity to the Seventeenth Century. Madison, WI: University of Wisconsin Press.

\section{About the authors}

Avril Behan is a lecturer in Geomatics (specifically remote sensing, photogrammetry, CAD, and land surveying) at the Department of Spatial Information Sciences, Dublin Institute of Technology. She holds a Master of Science Degree from Dundee University, Scotland, in Remote Sensing, Digital Image Processing and Applications and is completing Ph.D. studies at the Department of History of Art and Architecture, University of Dublin, Trinity College on the application of geomatics techniques to the analytical study of medieval window tracery in Connaught and Ormond, Ireland. Her other research interests include heritage applications of terrestrial laser scanning, CAD and visualisation, satellite remote sensing, airborne laser scanning, and the usage of Web 2.0 applications for higher education. She has presented at conferences such as CIPA/VAST 2006 on "Close-Range Photogrammetric Measurement and 3D Modelling for Irish Medieval Architectural Studies" and ISPRS Congress 2000 "On the Matching Accuracy of Raterised Scanning Laser Altimeter Data”.

Dr Rachel Moss is a lecturer at the Irish Art Research Centre in Trinity College, Dublin. A specialist in the field of medieval architecture and sculpture, research projects with which she has been involved include the electronic capture and archiving of medieval architectural details with the department of Computer Science at Trinity College Dublin, and she is currently working on a project that looks at medieval buildings as documents of social and economic change. She was also involved, in a consultative role, with the establishment of a state-sponsored national database of movable Irish field antiquities. She has published numerous articles on medieval art and architecture and edited/co-edited two books, Art and Devotion in Late Medieval Ireland (2006) and Making and Meaning in Insular Art (2007). 